\title{
Push-Pull Dispensing Plastic Container Closure
}

National Cancer Institute

\section{Source}

National Cancer Institute. Push-Pull Dispensing Plastic Container Closure. NCI Thesaurus. Code C96132.

A two-piece dispensing closure that includes a base member the lower portion of which is designed to attach and seal securely to a container finish and the upper portion of which is designed to receive a dispensing spout member. The spout member may be moved upward and downward to open and close the dispensing passageway. 